Open Access

\title{
Erratum To: Early pro-inflammatory cytokine elevations in the DBA/2J mouse model of glaucoma
}

Gina N. Wilson ${ }^{1,2}$, Denise M. Inman ${ }^{1}$, Christine M. Dengler-Crish ${ }^{1}$, Matthew A. Smith ${ }^{1,3}$ and Samuel D. Crish ${ }^{{ }^{*}}$

Following the publication of our article [1] we noticed that the author name was included incorrectly. Author name Christine $M$ Denger Crish in the original article should read Christine M Dengler Crish. The original version of the article has now been corrected to reflect this.

\section{Author details}

'Department of Pharmaceutical Sciences, Northeast Ohio Medical University, 4209 State Route 44, Rootstown 44272, OH, USA. ${ }^{2}$ Biomedical Sciences Graduate Program, Kent State University, 800 E. Summit Street, Kent 44240, $\mathrm{OH}$, USA. ${ }^{3}$ Integrated Pharmaceutical Medicine Graduate Program, Northeast Ohio Medical University 4209 State Route 44, Rootstown 44272, OH, USA.

Published online: 26 October 2015

\section{Reference}

1. Wilson GN, Inman DM, Denger-Crish CM, Smith MA, Crish SD. Early pro-inflammatory cytokine elevations in the DBA/2 I mouse model of glaucoma. J Neuroinflammation. 2015;12:176.

\footnotetext{
* Correspondence: scrish@neomed.edu

1 Department of Pharmaceutical Sciences, Northeast Ohio Medical University,
} 4209 State Route 44, Rootstown 44272, OH, USA

Submit your next manuscript to BioMed Central and take full advantage of:

- Convenient online submission

- Thorough peer review

- No space constraints or color figure charges

- Immediate publication on acceptance

- Inclusion in PubMed, CAS, Scopus and Google Scholar

- Research which is freely available for redistribution

Submit your manuscript at www.biomedcentral.com/submit 